\title{
MULTIPLIER AND CROWDING-OUT EFFECTS OF STATE AID ON PUBLIC BUDGETS
}

\author{
[Multiplikační a vytěsňovací efekty státní podpory podniků ve vztahu \\ $\mathrm{k}$ veřejným rozpočtům]
}

\author{
Pavla Brůžková ${ }^{1}$ \\ ${ }^{1}$ University of Economics in Prague, Faculty of International Relations, W. Churchill Sq. 4, 13000 Prague 3 \\ Email:xbrup05@vse.cz.
}

\begin{abstract}
The aim of this paper is to analyze, specify and isolate components that form the anticipated multiplier and crowding-out effects of state aid and to discuss its impacts on the public budgets. The author shows that some qualitative and hardly measurable aspects should be included in the multiplier effect. At the same time, various present crowding-out effects partially offset the expected positive results. Several key aspects of state aid are identified to influence the balance of public budgets. First, the distortion of prices of the production factors lead to adjusted tax and social security payments. Second, long-term changes of potential product caused by the provided state aid may create conditions for enhanced economic activity. Last but not least, administration costs connected to state aid should be carefully measured and evaluated.
\end{abstract}

Keywords: crowding-out effect, market failure, multiplier effect, public budgets, state aid.

JEL classification: $\mathrm{H} 21, \mathrm{H} 25$

Doručeno redakci: 6.5.2016; Recenzováno: 9.6.2016; 20.7.2016; Schváleno k publikování: 19.10.2016

\section{Introduction}

State aid to private enterprises and its effects at micro- and macroeconomic level have been an area of interest in many research papers. Likewise, it has also been a subject of some controversies among researchers, policy makers, entrepreneurs and the general public. The process of investigation begins at the microeconomic level when analysing the motives of any single enterprise as of whether or not to apply for state aid. Subsequently, some may even decide to adjust their business plans to the criteria of the aid programs. The willingness to perform such adjustment mostly depends on the form and amount of state aid offered and/or on a degree of certainty of obtaining such aid. Moreover, financial benefits as well as costs accompany such application and the provision of state aid. All these partial decisions of individual companies are then projected to the macroeconomic level - state aid for the small and medium-sized enterprises (SMEs) thus has an impact on the amount of gross value added and hence the economic growth, unemployment indicators and the state of public budgets.

The mainstream Keynesian economic theory uses a commonly known multiplier of government spending. However, various crowding-out effects and other specific features of state aid spending are not included in this concept. The aim of this paper is then twofold: (a) summarize relevant factors and to construct a model of the multiplier of state aid for private enterprises; (b) include the crowding-out effects present in these specific mechanisms and transactions and to present net effects on public budget induced by state aid programs.

According to the goals of the paper, the necessary theoretical introduction is followed by the description of methods and derivation of the model isolating the multiplier and crowding-out effects on public budgets as well as other components that deserve special attention. In the discussion, four most obvious problems are mentioned and analyzed. 


\section{Theoretical background}

Among many theoretical approaches to state aid provided to enterprises, two main directions should be mentioned as relevant regarded the scope of this paper. Again, the investigation carried out at the microeconomic level is later demonstrated in different macroeconomic indicators or maybe disorders. As presented, various theoretical approaches usually focus on some of the phenomena which accompany the provision of state aid or monitor its consequences.

Discussing the economic point of view, some authors search for a connection between state aid and economic growth (Minoiu, Reddy 2010), potential product represented mainly by investments in R\&D (Ferri 2015) or other macroeconomic indicators. Since state aid for private enterprises is mostly provided only in disadvantaged and/or less developed regions, the ,spatial“" or regional aspect of economic growth facilitated by state aid instrument is often examined (Karlsson et al. 2015, Farole et al. 2011, Barca et al. 2012). However, the results vary depending on the state aid instrument in question and on the sample and methodology used. At last, probably the largest group of research works deals with the question of state aid as an instrument to overcome market failures. These works then identify both positive and negative economic consequences of providing public goods such as social security (Aaron 2010), education, healthcare and other elements of so called „welfare economy“ (Kline, Moretti 2014).

The key issue of most economic-related disciplines is the way scarse resources are allocated while in some cases attempting to establish mechanisms for optimal allocation. In its simplest form, the problem stands as how to divide the total amount of given resources among alternative projects; in case of state aid, we may further specify the division between the public and the private use. Meanwhile, virtually every change of political and economic consequences affects overall economic efficiency and the division of revenues among the members of the society. The derivation of conditions of Pareto efficiency of resource allocation between public and private use was first presented by Samuelson (1954) and it is associated with the marginal utility functions for each of the public and private goods and the overall production-possibility frontier. The model is then based on the assumption that the amount of private goods produced depend on the amount of public goods, this resulting in an optimal combination of public and private allocation with the given amount of resources. The crowding out of private allocation and the opportunity cost of any public expenses is then present in the basic microeconomic theory (Hicks 1941).

Mainstream economics explains the provision of state aid using the argument of market failure, e.g. in some cases the market itself is incapable of ensuring efficient redistribution and through targeted modifications, it is possible to attain a higher level of welfare (e.g. Pigou 1932, Barr 2012). The most common types of state aid mentioned in the context of market failure are risky financing or loan guarantees for small innovative companies ("start-ups"), which in their infant stages of development find it difficult to raise capital from banks or private investors; further, we would mention direct subsidies for research and development including cross-border co-operation or large investment projects in the area of infrastructure (Zemplinerová 2006). From this perspective, state aid may act as an instrument of the secondbest policy; unlike the first-best policy, certain imperfections regarding the maximizing of the economic and social welfare may be experienced (Bhaghwati 1971). Nevertheless, it is still believed that the resources would be allocated more effectively than if the situations were left purely to market forces. 
The issue of market failure is related to the problem of information asymmetry. This may occur if one party has obtained more relevant information while this has been withheld (intentionally) or hidden (unintentionally) from the other party in the given relationship. State aid for enterprises often aims at eliminating certain information asymmetry, nevertheless, other asymmetries may arise in the actual process of providing aid. The information asymmetry between the state aid provider and the recipient may occur in both directions of this relationship; it may also happen among the different beneficiaries, depending on if and how closely they are connected to the government sector. The state aid provider has an "information monopoly" for the precise interpretation of rules and conditions, while the recipient is responsible for the proper management of all the administration processes. The cost of obtaining all necessary information may be prohibitive particularly for the SMEs, or may be larger than the expected amount of state aid (Lehner, Meiklejohn 1991). On the other hand, the government authorities are largely dependent on information which the companies themselves provide them; as a result, inefficient allocation or even loss of funds intended for state aid may occur (Rothbard 2001).

A specific type of information asymmetry can be observed in relation to foreign investors who are very frequently recipients of investment incentives and other types of aid. These entities are because of their ignorance of the local environment and the specifics of domestic enterprises placed at disadvantage as compared with the domestic enterprises (MonerColonques 2008).

The microeconomic and the macroeconomic levels are linked by the multiplier effect; as regards the state aid, we assume that the sale of products or services of a supported enterprise requires the sub-deliveries of products of services of another (unsupported) enterprise or other subject within the domestic economy. These presumptions then imply an increased aggregate demand in the economy which is also reflected in respective indicators of the public budgets.

Fletcher et al. (1991) use an input-output model and define the multiplier as the ratio of total change to the initial change. The final effects may be divided into direct effects (i.e. impact caused by the supported company itself); indirect effects (i.e. impact of the enterprises supplying goods and services to the supported company); and induced effects (i.e. increased overall expenses of the employees of the supported enterprise and its subcontractors in the given region). Effects expressed in this way thus permeate further and further subcontractor levels.

However, other authors point to some weaknesses of this concept including too many assumptions and estimates or large data files needed to implement a proper input-output analysis (Hall 2005). The multiplier demonstrates only the economic impacts while omitting resulting externalities or social and environmental aspects. Mainstream Keynesian interpretation in itself does not include negative economic effects, mainly the opportunity costs. In this specific case, the costs of the bureaucratic apparatus which administers the given program should also be included. Some authors, e.g. Rothbard (2001) mention further leaks of funds in the form of bribes or distortion of prices and the overall competitive environment. Both the micro- and macroeconomic effects of state aid may then result negative.

In the current theoretical and legal status, the state aid is mostly thought of as a market distortion factor; this trend is demonstrated in the regulations of the European Commission prohibiting the provision of state aid, although with many exemptions (Collie 2002). 


\section{Methods}

Generally speaking, the presented model has been constructed via an economic cost-benefit approach. This set of methods is most commonly used to evaluate the economic effectiveness of private or public projects, while often trying to monetize and include some non-market impacts or externalities. The bearer of the costs and benefits implying from the project is then usually the same subject - and let us assume that it is a private enterprise - and this single subject plans to realize the project and decides on its extent, sources of financing including possible state aid sources and other specifics.

In a decision-making process, a private enterprise uses cost-benefit analysis to reveal feasibility of the project and its economic, financial and non-economic aspects, some of which have to be monetized and estimated prior to the evaluation. Both costs and benefits can often be divided into certain cathegories (e.g. investment and operational costs) and may occur in a short term (e.g. direct investment costs) or in a longer term (e.g. enhanced know-how of the employees working on newly launched projects that result from the investment). Based on the results of the analyses performed, the enterprise picks one of the investment options available and/or adjusts its plans in order to achieve better value of selected indicators.

For the purpose of examining the impact of state aid on public budgets, we have to adjust the cost-benefit approach to a different point of view. First, the scope of examination is narrowed to projects that benefit from some form of aid. The bearer of the costs and benefits of such activity in question is the government authority. However, government authorities are not able to influence the form and extent of supported projects, while on the other hand, private enterprises may be motivated to adjust their projects in order to conform to the state aid rules. The cost-benefit analysis of the public budgets includes direct and indirect costs and income with applied tax rate(s) as constant(s) that strongly effect the overall result. This result may then be presented as cost-effectiveness that shows, for example, how much income to the public budget has been generated by one monetary unit of state aid.

We expect that the most serious limitation to this method may be the lack of relevant data. When applying this cost-benefit model, many components have to be estimated; the accuracy of this estimate then strongly influences the result. Feasibility of this model also depends on how complicated the tax and social security system is and how much it is needed to simplify the structure and rate of expected payments into the public budgets.

\section{Measuring of multiplier and crowding-out effects}

In the process of quantification of different effects of state aid on economic indicators and public budgets, it may be useful not to limit the investigation only on direct effects, i.e. effects caused by the supported project or enterprise itself but also on indirect effects which in fact take the role of externalities (e.g. increased traffic around a newly constructed leisure centre). These indirect effects are generally more difficult to quantify. However, an overall costbenefit analysis should cover all the elements and at least show the direction of the anticipated effect. Table 1 presents a summary of possible effects of state aid including derived multiplier/crowding out effects. 
Table 1: Summary of possible effects of state aid to private enterprises

\begin{tabular}{|c|c|c|c|}
\hline $\begin{array}{l}\text { Direct/indirect } \\
\text { effect }\end{array}$ & Manifestation in the economy & Effects on the public budgets & $\begin{array}{l}\text { Multiplier/crowding-out } \\
\text { effects }\end{array}$ \\
\hline $\begin{array}{l}\text { Job creation on } \\
\text { the regional } \\
\text { labour markets }\end{array}$ & $\begin{array}{l}\text { More effective utilisation of } \\
\text { production factors; } \\
\text { Increased income of employees }\end{array}$ & $\begin{array}{l}\text { Additional corporate and } \\
\text { employment tax revenue; increase } \\
\text { of revenue from indirect taxes; } \\
\text { Cost savings on social benefits }\end{array}$ & $\begin{array}{l}\text { Any new job induces } \\
\text { additional demand for } \\
\text { goods and services from } \\
\text { suppliers }\end{array}$ \\
\hline $\begin{array}{l}\text { Stabilization } \\
\text { and growth of } \\
\text { SMEs }\end{array}$ & $\begin{array}{l}\text { Overall improvement of the } \\
\text { business climate; gradual growth } \\
\text { of product potential }\end{array}$ & $\begin{array}{l}\text { Positive, but hardly quantifiable; } \\
\text { manifested mostly in medium and } \\
\text { long term }\end{array}$ & $\begin{array}{l}\text { Multiplier effect in a } \\
\text { longer term }\end{array}$ \\
\hline $\begin{array}{l}\text { Development } \\
\text { and transfer of } \\
\text { new technology }\end{array}$ & $\begin{array}{l}\text { Higher production volumes with } \\
\text { constant quantity of factors; } \\
\text { Innovation and competitiveness }\end{array}$ & $\begin{array}{l}\text { Additional corporate and } \\
\text { employment tax revenue; increase } \\
\text { of revenue from indirect taxes }\end{array}$ & $\begin{array}{l}\text { Additional demand for } \\
\text { goods and services from } \\
\text { suppliers, qualitative } \\
\text { effects }\end{array}$ \\
\hline $\begin{array}{l}\text { Development of } \\
\text { tourism and } \\
\text { other service } \\
\text { sectors }\end{array}$ & $\begin{array}{l}\text { Additional income from new } \\
\text { domestic and foreign visitors; } \\
\text { Increase of the human capital of } \\
\text { the employees }\end{array}$ & $\begin{array}{l}\text { Additional corporate and } \\
\text { employment tax revenue; increase } \\
\text { of revenue from indirect taxes }\end{array}$ & $\begin{array}{l}\text { Synergistic and } \\
\text { qualitative multiplier } \\
\text { effects }\end{array}$ \\
\hline $\begin{array}{l}\text { Economic } \\
\text { activity in } \\
\text { peripherial } \\
\text { regions }\end{array}$ & $\begin{array}{l}\text { More intensive use of local } \\
\text { production factors; growth of } \\
\text { product potential }\end{array}$ & $\begin{array}{l}\text { Possible cancellation of other } \\
\text { subsidies }\end{array}$ & $\begin{array}{l}\text { Synergistic and } \\
\text { qualitative multiplier } \\
\text { effects }\end{array}$ \\
\hline $\begin{array}{l}\text { Projects that } \\
\text { would be } \\
\text { implemented } \\
\text { without state aid }\end{array}$ & None & $\begin{array}{l}\text { Public budget expenditure without } \\
\text { appropriate increase of income }\end{array}$ & $\begin{array}{l}\text { Crowding-out of private } \\
\text { consumption }\end{array}$ \\
\hline $\begin{array}{l}\text { Demise of non- } \\
\text { competitive } \\
\text { businesses }\end{array}$ & $\begin{array}{l}\text { Shift of production factors to } \\
\text { another field of business }\end{array}$ & None & Crowding-out effect \\
\hline $\begin{array}{l}\text { Production } \\
\text { factor markets }\end{array}$ & $\begin{array}{l}\text { Stronger pressure on labour and } \\
\text { capital markets weakens other } \\
\text { positive effects }\end{array}$ & $\begin{array}{l}\text { Higher prices of production factors } \\
\text { may result in greater tax payments }\end{array}$ & $\begin{array}{l}\text { Partially offsets the } \\
\text { impact of the employment } \\
\text { multiplicator }\end{array}$ \\
\hline
\end{tabular}

Source: own elaboration

This overview of effects suggests that the precise measuring of multiplier and crowding-out effects of state aid is not as straightforward as the Keynesian multiplier of government spending since it bears certain longer term aspects connected with possible growth of the potential product and other rather qualitative changes. Likewise, the crowding-out effects are specific and often hardly measurable; the data concerning the extent of projects implemented even without state aid might be acquired only after a detailed interview with each of the beneficiary enterprises. Therefore, a series of presumptions and expert estimates are usually made, which in individual cases are also backed with ex ante and/or ex post assessments.

When deriving the model, let us come out of the assumption that the multiplier and crowding out effects of state aid are directly reflected in the state of public budgets. Also, we assume that a single rate of a corporate income tax (a), a single rate of indirect taxes (b) and a single rate of employment taxes (c) are implemented in the economy in question. In general, the overall effect of state aid on public budgets may be expressed as follows:

$$
E=T I N_{a d}+S S B_{a d}+M E-C E-S A C
$$


where TIN = additional tax incomes; SSB = payments of social security benefits, unemployment benefits and other similar payments that are no longer necessary due to higher employment and higher wages; $\mathrm{ME}=$ multiplier effects; $\mathrm{CE}=$ crowding-out effects; $\mathrm{SAC}=$ state aid costs (lowered tax revenue or public expenses) including costs of administration of the state aid programs.

Let us now attempt to isolate and specify these individual components. The additional tax income is strongly dependent on the tax system and tax rate(s) in an individual economy. It could be expressed as follows:

$$
T I N=a \times C T I_{a d}+b \times G V A_{a d}+c \times W C_{a d}
$$

where $\mathrm{a}=$ tax rate applied at direct corporate income; $\mathrm{CTI}=$ the amount of the additional corporate income generated due to the state aid provision; $\mathrm{b}=$ tax rate applied for indirect taxes; GVA = gross value added (additional output of supported enterprises generated due to the state aid provision); $\mathrm{c}=$ tax rate for employment taxes; $\mathrm{WC}=$ wage costs of employees newly hired due to the state aid provision.

The component of social security payments can be quantified as the number of the new jobs created as a result of state aid provision multiplied by an average amount of unemployment benefit and the corresponding entitlement period of these benefits (to make things simple, the maximum entitlement period may be calculated for all cases).

Let us now proceed to the component of state aid costs. Generally, only the direct costs of state aid are considered when analysing the costs and benefits of state aid while the administrative costs are omitted and rarely measured. These costs partly consist of the administrators' wages; the rest are mostly other costs supplied by external private parties that also act as tax payers (material, transport, office costs etc.). In both cases, a part of these costs is brought back to the public budgets in a form of an employment/indirect tax payment. Therefore, the impacts on the public budgets may be defined as follows:

$$
S A C=D C+W C+O C-b \times G V A_{a d}-c \times W C
$$

where $\mathrm{DC}=$ direct costs of state aid programs; $\mathrm{WC}=$ wage costs; $\mathrm{OC}=$ other costs.

Finally, under all the assumptions stated above let us attempt to isolate the multiplier and crowding-out effects. The measurable multiplier effect may be identified in two main fields: (a) additional income of suppliers; (b) additional income of employees in newly created jobs as well as the civil servants and other staff administering the state aid programs. In accordance with the traditional Keynesian interpretation, the multiplier effects depend on the marginal propensity to consumption/savings. Therefore,

$$
M E=b \times(N W-S)+a \times C T S_{a d}+b \times P S_{a d}
$$

where the (NW - S) component shows the net additional consumption of employees calculated as their net wage adjusted for total additional savings. The other two components then represent the suppliers: the $\left(\mathrm{a}^{*} \mathrm{CTS} \mathrm{Sd}_{\mathrm{ad}}\right)$ component stands for the corporate tax paid by the suppliers and resulting from their additional production; the $\left(\mathrm{b} * \mathrm{PS}_{\mathrm{ad}}\right)$ then stands for the indirect taxes resulting from this additional production. 
The last component in question are the crowding-out effects. Following the previous findings, we may summarize two main sources of these effects: the fact that due to newly set conditions including state aid provision in the competition, some enterprises have gone bankrupt; and the extent of the project that would be implemented even without state aid provision and where the state aid is then a waste of public funds. Similarly to the previous cases, the effect is demonstrated both on the part of companies and on the part of employees - consumers. Therefore, the crowding-out effects may be formalized as follows:

$$
C E=\left(a \times C T I_{b}+b \times G V A_{b}+S S B_{b}\right)+\left(a \times C T I_{C}+b \times G V A_{C}+c \times W C_{c}\right)
$$

where the first "source" of the crowding-out effect is covered by $\left(\mathrm{a}^{*} \mathrm{CTI}_{\mathrm{b}}\right)=$ the lost tax payments of companies that may have gone bankrupt; $\left(b^{*} \mathrm{GWA}_{b}\right)=$ the lost indirect tax payments resulting from lowered consumption of the newly unemployed from the bankrupt enterprises; $\mathrm{SSB}_{\mathrm{b}}=$ additional social security benefits paid out by the government as a result of the newly occured unemployment. The second "source" of the crowding-out effect is then analogous to the additional tax incomes described above and shows the relevant part of tax incomes that has been supported but would have happened even without the state aid provision. It is then obvious that rather than bringing purely negative results, the crowding-out effects weaken the overall or the multiplier effects formalized above.

\section{Discussion}

The production factor markets. Changes in the allocation of the production factors are generally considered as one of the most obvious consequences of state aid and often examined (Midelfart-Knarvik, Overman 2002; Fumagalli 2003). As shown in the model, both multiplier and crowding-out effects are present in this field, embodied in the demise of non-competitive business outlets as well as in the know-how and technology transfers. How would the production factor markets look like without the state aid provision is an opened question, mainly the extent of quantitative and qualitative shifts that would have happened if the market forces had determined the balance on its own.

The crowding out and demise of uncompetitive business outlets has its roots, among other causes, in the fact that the newly established and supported enterprises may "overbid" some employees with higher wages in its initial stage, thereby disrupting the optimum on the labour market; the same may be obviously applied to other production factor markets. If the mechanism of state aid provision is not properly set up as regards the localization of the new enterprises, some sectors in some areas may become strongly exposed to this "overbidding" in the short or middle term. This would be then reflected in the growth of wages that may not correspond to the growth of labour productivity which acts as a negative impulse on the side of aggregate supply with commonly known macroeconomic consequences on the product and prices. However, since the main scope of this paper are various effects of state aid on public budgets, it should be noted that these pressures on production factors may be rather positive in terms of increasing the wages and other payments and therefore also the total payments to the public budgets.

Decision-making and motivation of the enterprises. Related to the prior comment, it should be noted that the decision-making process in the enterprises is the primary source of the potentially incurred market distortions. Unlike other forms of public goods, the state aid for private enterprises is used on a voluntary basis and the motivation and decision of an every single outlet has to be present, the enterpreneur being also familiar with the downsides of the state aid provision as well as the benefits. In case of investment projects, we would mention 
the problem and availability of financing, the minimum required yield, the businnes risks, return on investments (ROI), market prospects or position of the competitors. Generally speaking, the investment activity supported from public funds usually runs at higher than optimal intensity. The possibility to finance part of the project in the form of non-repayable financial grants then pushes the boundaries of "acceptability" toward projects that would have been assessed as insufficiently profitable. At this point, however, the provider of state aid is obliged to thoroughly assess the company's future prospects and its ability to continue financing its own resources in the later stages of business. If the investment project does not have good prospects, a considerable risk of wasting public resources may exist.

When deciding on the specific content of the project, the parameters and conditions for the state aid provision express the intents of the government to support only certain economic activity; state aid thus becomes a tool of the economic policy. In some cases, the setting of public support may "encourage" enterprises to adjust the investment and other plans in the desired direction in order to obtain financing from the government. The actual definition of the economic policy priorities then plays a key role.

State aid provision may be a motivating factor even at the moment of decision on the location of the investment. The most common reasoning of state aid is to encourage the development of structurally afflicted regions and regions with a high unemployment rate. As mentioned in the previous paragraph, the setting of the state aid programs regarding localization has its direct impacts on the production factor market and the existence of pressures on these markets. From the enterpreneur's perspective, other aspects of localization such as accessibility and distance from the business partners and competitors play an individual role depending on the parameters of every single project.

Potential product. While many studies have been published focusing on the costs and benefits of state aid and attempt to quantify its various aspects, very little attention has been paid to its qualitative effects that could be manifested in a longer term. Using the recent experience from the the Czech Republic and other CEE countries, the muliplier effects of the state-supported FDI influx to the region in the last 20 years have been far-reaching mainly as regards the transfer of technology, know-how and management skills of the local workers. A properly set system of state aid also encourages synergistic and qualitative effects resulting from the gradual regional cohesion within one country. Improvements of the image of the country or region and improvement of the position of the SMEs should be also included, resulting in the overall improvement of the standard of living of the local people and massive developments and growth of demand in the area of services and tourism.

Administration costs. The presented model has shown that the most serious defect demonstrated in common cost-benefit analyses is that it underestimates the costs of preparation, administration and monitoring of the state aid programs. These costs may be easily derived using few components; with reflection to the public budgets, some of the funds are brought back to the public budgets due to a partial multiplier effect. Still, it is obvious that the calculations of benefits would result differently if these costs were included and properly measured. The administration costs have to be reflected also by the companies; an uncertain amount of state aid compared to easily quantifiable expenses on consulting services or extra employees may discourage especially SMEs with limited resources and tight budgets, while these enterprises are the exact target group of many aid programs. We need to mention that costs are not the only issue related to administration. The more structured and complicated administration for the application is requested, the more information assymetries, gaps and 
other further inefficiencies may occur in the mutual relationship of the state aid beneficiary and the provider. This topic, however interesting, is already outside the scope of this paper.

\section{Conclusion}

This paper attempts to summarize the author's understanding of broader effects of state aid, its main aim being to derive a model that would be applied to any state aid program and its data. The cost benefit analyses regarding state aid may be carried out in several directions; the one chosen here has been the effect on the public budgets. It generally confirmed that state aid presents a distortion of market forces; the investment and other economic activity when state aid is provided result more intensively, i.e. with positive impacts on public budgets but bringing along pressures on the production factor markets.

In its first step, the presented model isolates various types of costs and income to the public budgets that are connected to state aid. Apart from the direct amount of state aid that is provided to the recipients, personal and other costs related to the administration of the state aid programs should also be included in the analysis. The anticipated direct income (,,benefit") then consists of two main components: additional corporate tax income from the supported economic activity and additional employment tax and social security payments collected from the newly created jobs in the supported enterprises.

While these findings may seem rather obvious, the analysis continues with its second step that specifies broader economic implications of the provision of state aid. Multiplier effects result from enhanced consumption of employees who occupy the jobs created thanks to state aid as well as from increased activity of suppliers. On the other hand, the anticipated crowding-out effects reflect negative distortions of the prices of the production factors and distortions of competition.

The issue of administrative costs of state aid programs of both the government and on the side of enterprises has been underestimated, although its proper understanding may be the key to understand the problem of state aid as a whole. It influences strongly not only the total result of the cost-benefit analysis on the part of the government, but also the motivation of enterprises to apply for any aid in the first place and affects the cost-benefit balance on the level of any single enterprise. Also, the costs incurred to overcome any present information asymmetry must be included. On the part of the government, it should not be ignored that some projects supported would have been carried out even without state aid, in a form coherent to the actual needs and objectives of the enterprise. With this said, we should move to our next conclusion: while state aid being usually an instrument of economic policy, its foundations are set already on a microeconomic level.

On the other hand, hardly measurable and possibly positive effects of state aid as regional development, technology and know-how transfers, stronger competitiveness and other aspects may contribute to the growth of the potential product. Although this may be supported by actual long-term trends in macroeconomic indicators, the fact that these theses are so difficult to grasp will, for the foreseeable future, still create space for advocates of various directions in the possible role of state aid in any government's economic policy.

\section{Acknowledgement}

The paper has been prepared within the IGA research project "Evaluation of the effectiveness of support for tourism and regional development" at the Faculty of International Relations, University of Economics in Prague. reg. no. F2/12/2015. 


\section{References}

[1] AARON, H., 2010. Economic effects of social security. Washington: Brookings Institution Press. ISBN 978-80-81570-734-9.

[2] BARCA, F., P. McCANN and A. RODRÍGUEZ-POSE, 2012. The case for regional development intervention: Place-based versus place-neutral approaches. Journal of Regional Science, 52, 134-152. ISSN 1467-9787.

[3] BARR, N., 2012. The economics of the welfare state. 5th. ed. Oxford: Oxford University Press. ISBN 978-01-99297-81-8.

[4] BHAGHWATI, J. N., 1971. The generalized theory of distortions and welfare: Trade, balance of payments and growth. Amsterdam: North Holland. ISBN 978-14-128-3667-8.

[5] COLLIE, D. R., 2002. Prohibiting state aid in an integrated market: Cournot and Bertrand oligopolies with differentiated products. Journal of Industry, Competition and Trade, 2(3), 215-231. ISSN 1566-1679.

[6] EUROPEAN COMMISSION, 2008. Guide to cost-benefit analysis of investment projects [online]. [acc. 15th August, 2016]. Available at: http://ec.europa.eu/regional_policy/sources/docgener/guides/cost/guide2008_en.pdf

[7] FAROLE, T., A. RODRÍGUEZ-POSE and M. STORPER, 2011. Cohesion policy in the European Union: Growth, geography, institutions. JCMS: Journal of Common Market Studies, 49(5), 1089-1111. ISSN 1468-5965.

[8] FERRI, D., 2015. Subsidizing acceptability. European State Aid Law Quarterly, 14(1), 51-67. ISSN 1619-5272.

[9] FLETCHER, J. E. and B. H. ARCHER, 1991. The development and application of multiplier analysis. In: C. P. COOPER, ed. Progress in Tourism, Recreation and Hospitality Management, vol. 3. London: Belhaven Press, pp. 28-47. ISBN 1-85293-025$\mathrm{X}$.

[10] FUMAGALLI, C., 2003. On the welfare effects of competition for foreign direct investment. European Economic Review, 47(6), 963-983. ISSN 0014-2921.

[11] HALL, C. M., 2005. Tourism - rethinking the social science of mobility. London: Pearson Prentice Hall. ISBN 978-05-823-2789-4.

[12] HICKS, J., 1941. The rehabilitation of consumer's surplus. Review of Economic Studies, 8(2), 108-116. ISSN 0034-6527.

[13] KARLSSON, C., M. ANDERSSON and T. NORMAN, 2015. Handbook of research methods and applications in economic geography. 1st ed. Cheltenham: Edward Elgar Publishing. ISBN 978-80-85793-267-9.

[14] KLINE, P. and E. MORETTI, 2014. People, places and public policy: Some simple welfare economics of local economic development programs. Annual Review of Economics, 6(1), 629-662. ISSN 1941-1383.

[15] LEHNER, S. and R. MEIKLEJOHN, 1991. Fair competition in the internal market: Community state aid policy. European Economy, 48, 7-114. ISSN 0379-0991.

[16] MIDELFART-KNARVIK, K. H. and H. OVERMAN, 2002. Delocation and European integration: Is structural spending justified? Economic Policy, 17(35), 321-359. ISSN 1468-0327. 
[17] MINOIU, C. and S. G. REDDY, 2010. Development aid and economic growth: A positive long-run relation. The Quarterly Review of Economics and Finance, 50(1), 27-39. ISSN 1062-9769.

[18] MONER-COLONQUES, R., 2008. Entry in foreign markets under assymetric information and demand uncertainty. Southern Economic Journal, 74(4), 1105-1122. ISSN 0038-4038.

[19] PIGOU, A. 1932. The economics of welfare. London: Macmillan and Co. ISBN 978-14128-3667-8.

[20] ROTHBARD, M. N., 2001. Ekonomie státních zásahů. Praha: Liberální institut. ISBN 80-86389-10-3.

[21] SAMUELSON, P., 1954. The pure theory of public expenditures. Review of Economics and Statistics, 36(4), 378-389. ISSN 0034-6535.

[22] ZEMPLINEROVÁ, A., 2006. Efekty státní podpory podniků. Politická ekonomie, 54(2), 204-213. ISSN 0032-3233. 